増田：根本加代子さんに対する病態と鑑別 疾患の質問です，遮閉時間と遮閉回数の違いに よる効果のところをもう一度詳しく説明御願い 致します。という質問が, 福島医大の橋本弘子 さんからきていますので, 御願い致します。

根本：スライドを御願いします。一席の一番 最後のスライドです，左のグラフは，横軸が一 日の遮閉時間を示し，0.5時間から 4 時間に分 けてあります。それから縦軸に視力の回復を 0 から100\%にしてあります.それで，1日3〜4時 間遮閉すればその効果が85 90\%に達すること をあらわしています。これは 4 時間以上の遮閉 が無効ということではなく効果は限りなく緩や かに $100 \% に$ 近づいていくとお考えください. また，右のグラフは，遮閉総時間を 20 時間と一 定にして遮閉回数を変えてみたものです．先程, 1 日 1 時間, 20 回 (20日間)遮閉したものが最大 の効果を得ていると報告しました。それは，10 時間を 2 回するよりは（要するに，これは 10 時間を 2 回だけに限って行なったものですので, 10時間を 2 回だけするよりは) 1 時間を 20 回 (20 日間)遮閉した方が効果があったということを 意味します。一日の $3 \sim 4$ 時間の遮閉が終日遮 閉に勝るものではなく, $3 \sim 4$ 時間でも継続し て行なえば十分効果があるということです。ま た, 終日にしたからといって, 7〜8倍の効果 が上がるものではありません，以上は，全て感 受期に治療を行なったものであることを確認さ せて頂きます。

増田：橋本弘子さん, よろしいでしょうか.

高木：あのちょっとわかりにくかったんで すが，20時間を 1 日 1 回やるよりも，1時間を 数回やった方が効果があったという，事でしょ うか.

根本：はい.
増田：1日20時間遮閉するにしても, 眼を 開けている時間はそんなに長くないですが。

根本：1日10時間を 2 回です。これは, ネ コの実験です。

増田：わかりました。 パネラーの先生方は, 遮閉を何らかの形で取り入れていらっしゃいま すが，特に遮閉時間について何かアドバイスが ありましたらお願いしたいのですが。例えば， 1 日中 eye patchで過ごさせなくても，3 時 間なら 3 時間だけ遮閉をさせて，その間弱視の 集中訓練をさせた方が苦痛も少なくてより効果 的だった，というような経験をお持ちでしたら それをお願い致します。

屈折矯正と遮閉は弱視訓練の基本ですが，遮 閉時間を決める根拠は何か, 例えば, 視力の程 度にもよりますが，長時間すればするほど訓練 効果は上がりますが，斜視を誘発したり，また， 心理的影響, 子供の性格, 環境などに, 左右さ れてしまうことがよくあります。

そこで, 私たち ORTが弱視のマネジメント をする際には，具体的に遮閉時間を指導する訳 で, 今回発表されたデーターによれば, ネコの 実験ではありますが，1日 $3 \sim 4$ 時間毎日すれ ば，最も効果的だったということで，これから 遮閉時間を決める際に大変参考になりました。 では，次の質問に移らせて頂きます。

高木：次の質問は，第 2 席の川瀬芳克さん に，川崎医大の深井先生から質問がきておりま す. 3 歳児健診に積極的に取り組んでいらっし やることに対し，敬意を表します。ひとつ，ど の程度の市町村でこれができると思われます か?

名古屋のごとく大都市のみか. 2 番目に, 社 会一般からの要望はどの程度ありますか？ と いう 2 つの質問です。川瀬さんよろしく御願い 
します。

川瀬：ふたつとも大きい問題で答えられるか どうかわかりません．まず，人口との関係です けども, 今回報告いたしました知多保健所の年 間出生数は約 2,600 位と思います。

私共が当初始めた頃は，4,000 少しあったと 思いますから，かなり出生が減っております. 他の例では碧南市という三河湾に面した市があ ります。ここでは，自治体，医師会，住民代表 の三者で, 碧南健康を守る会という組織が作ら れていまして，そこで， 3 カ月， 1 歳半， 3 歳す べての健診を通して行なってます。

斜視スクリーニングもこのなかに組まれてい まして, 開業医の先生方が，スクリーニングを され，私共でその精検を担当しています。ここ の人口がまた違います。その他に，アンケート だけ実施しているところがあります。確かに， 大都会あるいは人口集中しているところという のは, 対象者の把握が難しいところがあると思 います。しかし，東京のいくつかの区でスクリ ーニングされてるとも聞いております。

ちょっと答えにはなりにくいんですけども， どこにでも適用できる，すぐれた汎用的な方法 というのはなくって，そこの地域によってやり 方を考えるしかないであろう…と考えます。

過疎地は過疎地のやり方があると思いますし， 人口密集地でしたらやっぱりそれなりのやり方 があるだろうということで，むしろ具体的な対 象地区をみた時に，そこの方策を考えたいと思 います。

人口でどれくらいであったらできるかという 答えにはなりませんが.

高木： 2 番目は, 社会一般からの要望はど の程度ありますかということです。

川瀬：視力診断部の方に, 直接要求が住民 から来るわけではありません。第一線にいる保 健婦や保健所の方にそうした要求が出されてい ます、スクリーニングを行なうなかで私共が考 えておりますのは, 仮に私共が出張していって もあくまでもスクリーニングの主体は保健所で あるということです.

ですから，受診者の人に，あなたはこうこう こういう異常があるから県の総合保健センター
で眼科的検查を受けなさいとか，こういうこと が必要ですよ，という指導はすべて保健婦がや ります。こちらは直接はやりません。

保健所あるいは地域でおこなってる活動は, 保健所が前面にでてもらって，それで，こちら はあくまでもサポートという体制です。そうし たなかで，住民の方からの声は先ず保健所には いります．他の例では, 北陸の辰口町では住民 からの要望から町により 3 歳児健診でのスクリ ーニングがなされ地域の病院が担当し, ORT も参加していると聞いています。

高木：どうもありがとうございました。

我々，治療する側に立ちますとやはり早期発 見, 早期治療が願ってもないことなんですが, やはり ORTが 3 歳児健診とかに積極的にで かけていって，それから行政面を動かしてと かいうふうに，各地方々によってやり方が異な っていると思います。また，ある方は ORT と して一生懸命できる範囲内で, さっき言われま したように，保育園とかそういうところに積極 的にいって 3 歳児健診を行なっている，という 人たちのお話も 2,3 お聞きしています。愛知 県での積極的な御活躍に対して, 敬意を表しま す.

川瀬：あのちょっと今思いついた点ですが, 追加させていただきますと，スクリーニングす ること自体は，技術的にはそれほど難しくはな いと思いますが，スクリーニングを計画される 際には，長期に渡り継続できるか，スクリーニ ング後のフォローアップは十分できるか，どの ような疾患をいかにして検出するか，見落とし などの対策はどうか, 等について, 十分検討し ていただきたいと思います。

深井先生どうもありがとうございました。

高木：次の質問に移らせていただきます。

増田：小林さんの健眼遮閉とその他の治療法 の比較というのに対して, 福島医大の橋本弘子 さんから，ペナリゼーションは，ケースを選ベ ば有効な治療法だと思いますので，もう一度ケ ースを選んで検討されてはいかがですか，とい う追加がありました。

小林：まず第一治療としてアイパッチを取 り入れたという症例がこんなに多かったんです 
けれども，その他には，ペナリゼーションとか Moore-Johnson 法とかを取り入れるケースも， 現在うちの病院に来ている患者さんの中にたく さんいらっしゃると思うんですけれども，今回 は一応，うちの病院の斜視クリニックというの を受診した患者さんを無差別に 50 人選んだ中で 検討していますので，もっとたくさんこのよう なペナリゼーションを行なった患者さんがいる と思いますので, 今後比較検討してみたいと思 います。ありがとうございました。

増田：大変興味があるのですが，ちょっと 教えて頂きたいのですが，不同視がある弱視で は, near penalizationの場合左右のレンズ差 がますます強くなってしまいますし, far penalization では, レンズ差は少なくなりますが, 健眼にアトロピンを入れますので，遠方視が健 眼でも患眼でも見にくいので，メガネに慣れる 前に子供が眼鏡装用を嫌がったり，わざと鼻眼 鏡にしたり，時々しか装用しないとか，アトロ ピン点眼を非常に嫌がったりで，治療効果が見 極めにくいことが考えられますが，そんな症例 はありましたか。

小林：もちろんありました。それで 1 カ月， 2 カ月でやめるのでなく, ある程度, 最低半年 ぐらいはやったケースもけっこうあったんです けれども，それでもだめだというケースに対し ては治療法を変えて行なっています。

増田：ありがとうございました。それでは 次の四番目の帆足さんに対して。

高木：第 4 席に二つ質問がきています。岥 阜大学の浅野さんから第 4 席の帆足さんに. 国 民的事業としての 1 歳半から 3 歳児健診がなさ れぬ限り，ORTにとって遮閉，アイパッチに よる遮閉法などと，それによる？との戦いは 永遠に続くものと思われます。

しかしながら，その日をただ待っていること はできません，ORTにとって，ここは! と 思う存分力をかけ，科学的かつ人間性にあふれ た患児，家族との係わりの中で治療の必要性を 説いていく他はないと思います。治療開始当初 に入院治療を，と御考えのようですが，健康な 子供たちを病院へ入院させてまで行なうことに ついては一考が必要なのではないでしょうか,
いかがなものでしょうか，という質問です。

帆足：報告いたしました時に多少言葉不足が あったかもしれませんけれども，(当初視力が） 一番最初から入院治療したほうがいいと言った わけではありません，今回データーに出してお りませんけれども, 半年から 1 年をみれば, 1 年をきちんとやった症例では，そこらあたりで 非常に視力が上がるという傾向もありました。 1 年間ぐらいで，なかなかやれておりませんと， その後延々と, 私が今回出しました症例でも 9 年とかいうのがありましたけれども，今後はす るだろう，今度はするだろうと，ずっと続けな がらやっているわけですね。

そうすると, 子供に後からよく聞きますと, やっぱり病気があるということと, 病院に来な ければならないという事が, 大変な重荷になっ ているということもありますし，また親の側か ら言わせれば，これだけ何年間も病院にかかっ ているのにこの病院は治してくれない，という ような苦情を聞くこともあります。

で，健康な子供を入院させることを，どんな ふうに考えるかということですけれども，確か に身体的には健康ではありますけれども, 視力 障害というハンディキャップをしょっていると いうことは完全なる健康だとは思っておりませ ん.ですから，それはもちろんケースバイケー スであることは忘れてはならないことですけれ ども，弱視治療を私たちが今回調查しました時 にも，漫然と，ただ長くやっている子が多いと いうことが，大変大きな反省点でした。患者の 家庭の状態とかそういうことも考えなければい けませんけれども，例えば半年間なら半年間, 健眼遮閉をしっかりやってみて，そしてそれが うまくいってない, これは長くかかる, 恐らく やれないだろう，ということがあったとしたら， 例えば延々と入院させるということではなくて， 一週間，二週間でも遮閉の習慣をつけるとかい うような目的でも入院治療をさせることは非常 に意義のあることだと思っております。

確かに, 健康な子供を病院の中につれてくる ということは，患者にとっても，それからそれ を受け入れる……あの, 特に熊本大学は子供病 院というような形ではありませんので，他の一 
般の患者との係わりからも，あまり健康な子供 が入院してくることは歓迎されることではない んですけれども，できるだけ短期間により効果 的に治療するためにはそういう方法を，これか ら先は考えていく必要があるのではないかと思 っております。

それによって結局，治療の期間が短縮される 可能性がありますし, 早く視力障害というハン ディキャップからある程度とれるということも， 長い将来を考えていけば, 入院も子供にとって は短い試練の場ではないか, と思われるからで す.

そこのところは，健康な子供を入れるという ことではあまりこだわっておりません。

高木：それでは，次の質問に移らせていた だきます。川崎医大の難波さんからです。

私共は, POMR, モンタージュ型記録方式, および電気生理学的検査などによって異常因子 の発見に努めており有効な方法ですので追加を いたします。

ところで質問ですけれども，難治症例の予後 の判定を行なうための訓練前のデーターをどの ように出しておられますか，という質問です。

帆足: 訓練前一応眼科の, 弱視というか一 般検査をやりまして，その中から私共ところで は，その POMR という方式をやりたいという ことは, 思っているんですけれども，まだ完全 にそこら辺までいっておりませんので,一般的 に視力, 固視のチェック, 眼位のチェックとい う形でやっております.それでよろしいですか.

高木：では，川崎医大から今回シンポジスト として出席されています早川さんに, 電気生理 学的な検査法によって, その異常因子の発見, また今回発表されました空間周波数 VEPを測 定することによって, 難治症例の予後の判定と いうことに役立つかどうか, そのことについて 私共から御願い致します。

早川：私共では, 個々の症例について POS (Problem Oriented system)で分析しており， 具体的には視力・両眼視機能・眼位など入力系 から出力系までの検査を行なう。その上で電気 生理学的分析を施行し総合的に異常因子を挙げ ていく．斜視弱視の電気生理的所見をみると
Flash VEPでは反応の減弱及び偏り, SVEP では網膜レベルから存在する反応低下・健眼刺 激時の後頭葉視中枢の反応の偏りが検出される. SRTでは健眼と患眼との運動潜時の差が非常 に大きい. 空間周波数 VEPの結果は本日お示 ししたが，斜視弱視難治症例の予後の判定まで は現在のところ難しい.ただし不同視十斜視弱 視のような例で高周波域反応が著明に低下し低 周波域反応が優位であれば，斜視弱視の要素が 強いと考えられ, 弱視治療のプランニング及び 患者指導の際有用である.

高木：ありがとうございました。難治症例 をいかに早期に発見するかということも，その 治療に対する，患者さんに対する負担等そうい うことを考え合わせますと, 早期発見するよう に我々も努力しなければいけないと思います。 それでは，次お願いします。

増田：第 5 席の偏心固視弱視治療後の両眼視 機能についてを発表された工藤さんに対して, 安永さんから，眼圧をどのくらいの頻度で測定 されていますか？ また，眼圧測定不能の年齢 では，どのように対応されていますか？とい う質問です。

工藤：えーと，あの，アトロピンの使用の ためにですか？

増田：そうですね, 安永さん？

工藤: 私共は, 弱視訓練として Cüppers 法 を中心にやっておりますが, 訓練の際にはミド リンで散瞳しております。

増田：この質問は, 健眼遮閉とその他の治 療法について発表された小林さんが, Penalization やMoore-Johnson 法で散瞳をしていら っしゃいますので，小林さんにもお願い致しま す.

小林: 一応, Moore-Johnson 法の効果はど のくらいででるかということに関して, 最低半 年ぐらいはやっているんですけれども, それで どの程度視力があがっているかどうかっていう のをみるわけなんですが，私共の病院では弱視 治療をおこなうにあっては 1 力月に最低一度は 来院させるっていう方法をとっていますので, 毎回毎回っていうことではないですが, 最低 2 カ月に一度くらいは検査を, 眼圧を測るってい 
うことをしております. 眼圧を測れないほどの 小さい患者さんっていうのはまだちょっと…… やったことがないのでちょっとお答えできませ 几.

増田：そうですね。アトロピンを長期点眼し て子供の緑内障の発作, つまり, 眼圧があがっ たというのはあんまり経験しないですね。とい うのは, 大人では眼圧を測らないでいきなり散 瞳剤は使いませんが，子供では眼圧を測らなく ても，アトロピンやミドリンをしょっ中使いま すが，発作が起きたということは，ほとんど経 験しません．Doctor は触診していますね．6歳 の子供にシェッツや自動眼圧計を使う先生もい らっしゃるかもしれませんが，そこのところは Doctorの管理下にあるわけで，この点に関し ては, Doctorの指示どおりに行わなければい けません。

アトロピン点眼に対する私の経験ですが，部 分調節性内斜視かもしれないが，眼鏡をかけて も，今一つ眼位がまっすぐにならない.でも， 調節によって眼位が正位らしくなったりで変動 している疾患に, 調節を完全に取るために両眼 にアトロピンを 3 カ月入れ続けて, 調節麻痺状 態にして，もちろん眼鏡も掛けさせて，眼位が ぞうなるかをみたことがあります。そのときで も，やっぱり眼圧が上がって発作が起ったとい うことは, ありませんでしたので, 追加させて いただきます。

次に, 工藤さんに対して,川瀬さんから. 両 眼視と視力の相関が示されていましたが，両眼 視の尺度はどのようにされましたか？ また， 視力を対数化されなかったのは, 何故ですか? という質問がきております。

川瀬：あの，両眼視の尺度化について質問 したつもりなのですが，縦軸に両眼視を0〜100 までとられてましたけども，そのような尺度を どのような標準化でもって作られましたか？ 相関を出すためには，両眼視を間隔尺度にされ たと思いますが，どのような方法でされたのか， 又その時に横軸に，小数視力をとられていたと 思いますが, 間隔尺度への変換はどうされたの でしょうか, という意味です。

増田：では，そういうことでお願い致しま
す。

工藤：はい, 今回はちょっと省かせていただ いたので，説明が足りなかったのですけども， 行ないました検査項目は先程お示しした15項目 で,この成績を比較するには, 点数化して比べ た方が分かりやすいということで， 5,6 年前に 自治医大山本が第 1 報から第 4 報に分けて, 弱 視の両眼視機能の研究という, 報告させていた だいてますが, そこで, 詳しく説明してありま すように，チトマスを除いた検査については, パスしたものを 1 点, チトマスは他の検査との バランスを考え, アニマル 1 つ正解の場合を $1 / 2$ 点, サークル 1 つ正解の場合を $1 / 3$ 点として 計算しますと，17.5点という数字が出て来ます. それを 100 としまして単純計算し, 先程のグラ フ値を出したわけです。

そこで, 確かに, 御指摘の通り, 今回はその まま少数視力との関係を検討しましたので, 対 数視力との検討はしておりません.

川瀬：相関を出される場合には，それが可 能となる尺度に直されるか, その他の方法で 処置されるのが適当と考え，質問いたしました。 ありがとうございました。

工藤：はい, 今後そのような方法で検討させ て頂きます。

増田：統計的方法には，データの採り方，ま とめ方，いろいろな方法があるようなんですね. それは又の機会にしまして, 次の質問に移らせ て頂きます.やはり工藤さんです.

シノプトフォアでは両眼視が得られるが，チ イトマスの Fly Testでは両眼視が得られない. で，チトマスで立体視が出ていない理由をど のように考えていらっしゃいますか. 例えば, 偏心固視があって治っても, 微小角斜視を残し たとか, ARCがあったとか, そういうことが 考えられますでしょうか？ということを川村 会長から御質問がありました。

工藤：それは私共もわからない問題なのです が，視力はかなり良いところまで改善していて 1.2 出ている症例もあります。で, 眼位も視力が 出てくるにつれて, もともとあった角度が減つ てきているものもありますし，最終的な段階で 残った場合には，それに対して手術をしたり， 
プリズムで両眼視できる範囲にしてやっていま す.それでも，なおかつシノプトなどの器械的 な検査下での両眼視は良くできるのに，日常両 眼視ができないという状態で足踏みしている症 例が多いので，ここから先どうしたら良いか， 私たちも悩んでいるわけで, 先程述べましたよ うに，今後に残された問題ということでお話さ せていただいたのです。

この様にどうしても日常両眼視ができないか ということが, 微小角やARCの為か？という ことは，もしできましたら電気生理をやってら っしゃる川崎医大の方からコメントいただけた ら幸いかと思うのですけれど…....

私共では，網膜対応についてはシノプトで検 査してますが ARC様にでたものはございませ んでした。

増田：そうですね. 両眼視細胞っていうのが 関与してるだろう思うんで，そういうところを 電気生理で追求しておられる深井先生御願い致 します。

深井：川崎医大の深井でございます．あの突 然の御指名で何かよくわかりませんです……あ の私も実は同じような御質問しょうと思いまし て，書きましたら非常に質問が多いと言うこと で，ちょつと辞めたわけなんですが，第 4 席の 問題となるかも知れませんが，やはり，あの治 る症例か, 治らない症例か.......

それから，その後両眼視へのアプローチの場 合に, 何が原因で立体視が付かないのか, やは りこれは電気生理学的にのみならず, やはり両 眼視の一般的検査でもある程度の判別は付くと 思います。

いちばん大きな問題は，私は眼位が残ってい る，で，眼位も非常に克服できる眼位と，そう でない眼位とがあると思うんです。で，Acc． ETの場合には，眼鏡をかければ両眼視は十分 出来るけれども, 最終的には眼鏡をかけないで 自分で調節と輻輳をリラックスさせる訓練をさ せながら，両眼視を植え付けていかないといけ ないと…..実際には言われているんですけれど も，またそういう場合にも，斜視の角度という のは，非常に大きな原因になってくると思いま す.
もう一つは,やはり上下の斜視というのが, 私は，かなり大きな原因ではないかと思います。 それから，私共の電気的な検查の結果では，や はり視力は両眼とも正しく揃えておかなければ ならない. その視力というのは, $1.0 な く て も ，$ 両眼共がかなり同等の視力が要るということで, 私共は電気生理学的に確かめております。

それから，これはまだしている段階のものな んですけれど, 両眼視のVEP というのを，い ま粟屋先生のおつくりになったランダムドット ステレオグラムで，とっているわけなんですけ れど，ああいう，いわゆる自然界には無い両眼 視と, 我々自然界にある両眼視というのは非常 に異なったものではないかという印象をもって おります。

これは, ARCの問題も，その中に非常に浅 いARCもあるかも知れません。その原因とし てですね，それは，これからアプローチして行 きたいとおもっております。

増田：どうも突然で有難うございました。

確かに弱視訓練をして視力が 1.0 になったか ら訓練を終わるというんじゃなくて，1.2まで 上げて，健眼が 2.0 ある場合には，0.8，0.9では

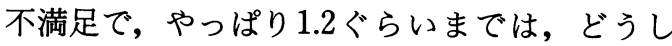
ても出さないといけない.また, 視力の測りか たが問題になりますが, 視力を測る場合に, 昔 から健眼をちょつと強く押さえると患眼の視力 が 1 段階くらい良くなることを経験します。こ ういうことから，両眼を開けてる時には，たと え視力が良くても健眼から抑制がかかっている。 だから，片眼を隠したら，1.2見えても，両眼開

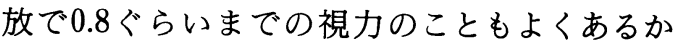
ら，両眼開放視力を測ることも必要になってき ます。

それで，そういうふうなこと以外に，X cell, Y cell, 電気的に dominant, slave が消えるま で訓練していけば，一番いいんじゃないかと… 川村会長の御質問に返って，眼位も良くなっ て，視力も良くなったのに Fly test が出来ない という症例に対して，両眼視がなぜなかなかて きないかということについてですが，山本先生 もいらっしゃいますのでなにかコメントいただ ければ幸いと思います。 
山本：自治医大の山本でございます，今日は， まずこの研究会に参加させて頂きましてありが とうございました．私共のところでわからない といって出した演題ですから，私にも何もわか つていないのですが, 1 つは, 私の恩師の原田 政美先生は, こういう偏心固視弱視というのは 先天的な単眼視であると, ですから両眼視出来 ないのが当たり前であって, そういうものは克 服出来ないものだという意見をお持ちでござい ます。

でも私は，乳児の時に偏心固視を治したよう な症例では，両眼視がでてくる例もありますし， 先天的で克服出来ないというようには, 決めた くないと思っています. 自分で考えていること は,いままでのCüpper'sなり, 何なりが, 全 部あまりに単眼固視にこだわりすぎて単眼視の 訓練をさせているのではないかということです。 もっと早期から単眼視をやめて両眼視をさせ る訓練法を考えていけば，良いのかということ で，もちろんそれにはシノプトを使って色々な やり方がいまでもあるわけです。しかし, 先程 工藤が申しましたように，それをやることによ って中心固視の獲得が遅くなるということがあ るものですから，躊躇してしまいますので，そ の辺をどうしたらいいかと考えておりますけれ ども，全く推論でございます。

増田 : 確かに先生のおつしゃる通りで, 私共 も片眼を遮蔽すると，それは両眼視を立ち切る ことですから，あまり長期間続けたくないわけ です。しかし，弱視があるとそちらを早く治さ ねばなりません。そのためには, 遮閉は効果的 ですから，いっしょうけんめい遮閉をさせてし まいます。両眼視の訓練もカイロスコープやシ ノプトで，当然併用しますが Fly test可能にま ではならないということをよく経験します。

何故, Fly test だけ出来ないのか, 内斜の夕 イプ, 弱視の有無, 治療方法等によって, Fly testが良好なものや, 不能なものが出て, 機能 的治癒の基準が変わることもあります。検査や 訓練をする際は微小斜視, わずかな ARC, 抑制 の検出に十分な留意が必要かと思います.

高木：以上で討論箱に入っていた質問は，こ れで終わりなんですけれども, 最後にこれだけ
はどうしても聞いておきたいと思われる方はこ の場で御手をおあげください.

何かございませんか?

今までに沢山の質問が出ましたけれども，今， この会場で思いついてこれだけはどうしても聞 いて帰りたい,ひとつだけは頭の中に入れて帰 りたいと思われることがありましたらどんなこ とでもいいですから，御質問をお願いします。

増田：無いようでしたら，私から一言，早川 さんに対して。

弱視斜視の電気生理的な検索という，これは 大変りっぱな御研究だと私は思います。例えば,

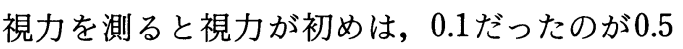
になりました。これは自覚的な検査なのです。 ということは, 他覚的に捉えていないから, 説 得力にいまひとつ欠けるところがある。で, $\mathrm{X}$ cell, $\mathrm{Y}$ cell とかそういうレベルで空間周波 数, 高周波数が, X cellですか高周波数が回 復したとかあるいは低周波数が良くなった，そ ういうレベルで弱視が治癒したというを判定し ていらっしゃるわけですから，これは，他覚的 に治癒を捉えるという意味で非常に有意義なこ とだと，私は思っているわけです。

早川：御追加有難うございました。

増田：川村会長の卒後教育及び生涯教育に力 を入れたいという方針に基づき，日常最も多く 取り扱っている “斜視弱視”がテーマに決めら れました。テーマがとても大きすぎて，これ一 つで視能矯正学の大半を占めますが, 基礎編, 検出と予防, 臨床, 研究と各部分にわけて 6 人 のシンポジストの先生方に御発表して頂きまし た.テーマをそれぞれの角度から考察していく と, 問題が山積されていて, 我々 ORTが最も 得意とする訓練一つを採っても病態が多様であ るため，まだ完璧とは言えないようです．これ らのことを一言でまとめることは到底出来ませ んでした．斜視弱視は大変興味深いものがある ということを再確認して研鑚に励んで頂ければ 幸いです。

本日は不勉強な私がこのような高い席で座長 を務めさせて頂き大変恐縮です.

パネリストの先生方, 及び多数御出席頂き活 発で有意義な質疑応答をしていただいた会員の 
皆様に感謝申し上げます。また，このようなり つぱな会場の提供とお世話頂きました原沢副会 長はじめ東京医大の皆様に厚く御礼申し上げま す.

\section{世界のメガネを あななに!}
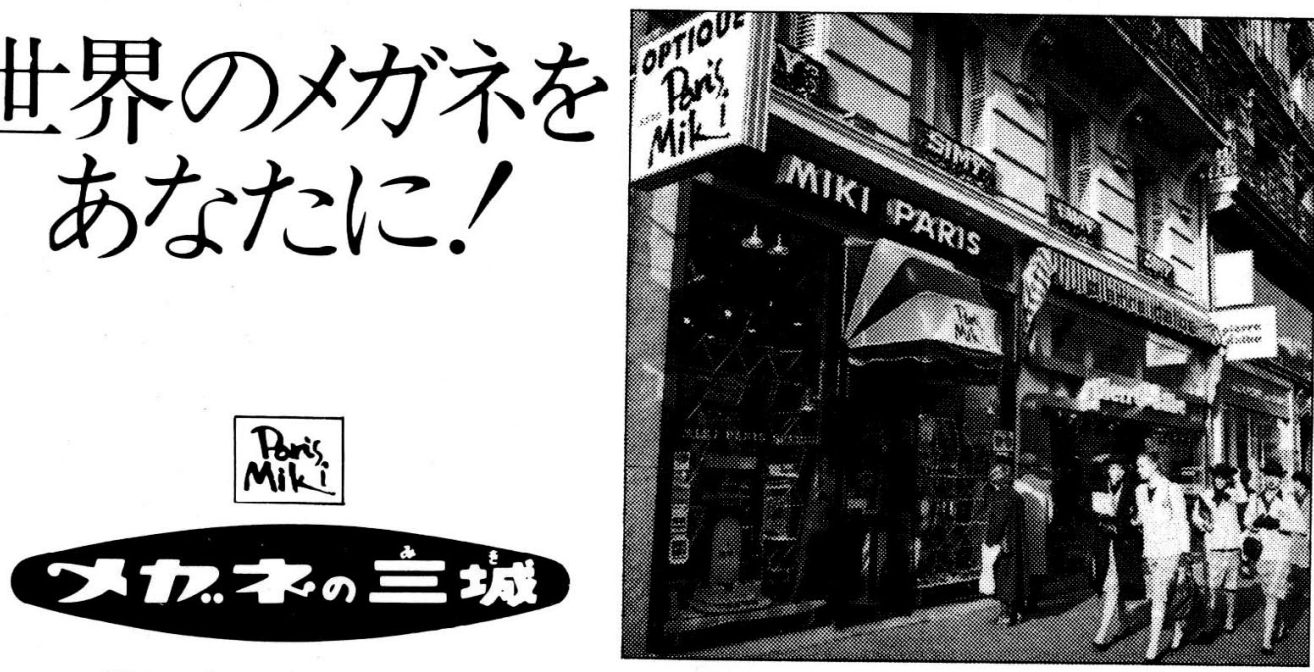

\section{熊本店}

熊本市下通1-3-10 (צ1工一城屋熊本4階) T (096) 353-2613

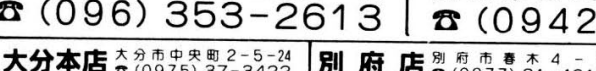

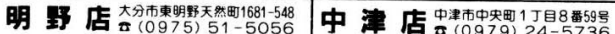

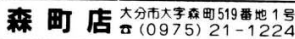

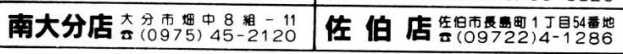

\section{鳥栖店}

鳥栖市古賀町 328 番地の 1 82-4020

\section{佐賀本店}

佐賀市鍋島町八戸溝293-4 8)(0952) 31-1577

\begin{tabular}{|c|c|c|c|}
\hline 大分本店 太貿 0975 市中 & 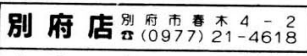 & 門 司 店北 $(093) 391-7881$ & 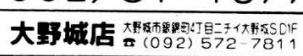 \\
\hline 明里店夻分市 & 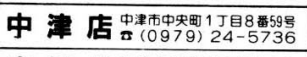 & 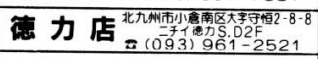 & 佐部本店等 \\
\hline 森 町 店态 & 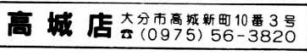 & 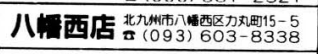 & 前栖店： \\
\hline 南大分店 太 & 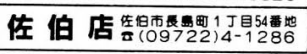 & 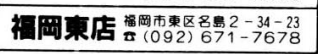 & 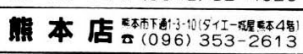 \\
\hline
\end{tabular}

